\title{
THE STUDY OF THE LEGAL ASPECTS OF DIVORCE IN KERMAN
}

\author{
Sakineh Esfandiari Mahni \\ Department of Private Law, Persian Gulf International Branch, Islamic Azad University, Khorramshahr, \\ Iran \\ Sadegh Alikhani \\ Department of Private Law, Persian Gulf International Branch, Islamic Azad University, Khorramshahr, \\ Iran
}

\begin{abstract}
According to Article 1133 of the Civil Code which is based on Islamic law is passed, man to divorce his wife whenever he can. Legislator for the restriction of the article, limiting the rights of women and protect the rights of a woman whose husband divorced her, the measures considered. The implementation of the right to divorce, the man is confined to the ritual of going to court and getting certified and nonadaptation. On the other hand, women are considered legal for couples divorce is required to play it. Some other aspects are not mandatory and is required if the couple agreed that the stipulation is made; The dowry paid on the basis of indicators of inflation, and school fees and alimony saying a few days. Some of these rights are mandatory aspects of the law amending the provisions relating to divorce and sent reckon such as the requirement that couples split-half assets acquired during the marriage. This study aimed to investigate aspects of divorce and applied in Kerman. A description of the survey methodology that statistical population of 50 counts of divorce cases in the Family Court in Kerman randomly selected using SPSS software to analyze the data was discussed. And came to the conclusion that the legal aspects like non-payment of dowry, the difference in pay maintenance, non-compliance, lack of legal information to couples are the main causes of divorce cases in Kerman along with other social factors.
\end{abstract}

Keywords: rights, divorce, alimony, dowry, couples

\section{INTRODUCTION}

Divorce of the most important phenomena of human life, the phenomenon has a framework and dimensions of all aspects of human society, Prime divorce is a psychological phenomenon. Because the psychological balance not only between humans, but children, friends, relatives and close friends affects them, secondly divorce economic phenomenon, in the sense that it could be "family" as an economic unit on its feet. And also in the sense that an economic factor such as "family income" in general, "poverty" causes of family disintegration, the last of the divorce phenomenon affecting all aspects of the population in a society; Because, on one hand, the effect on the population quantity, since the only legitimate and fundamental group unit of reproduction, the family falls apart. On the other hand, the population quality effect because it causes the children to be deprived of the blessings of family, community delivery which is likely to have a community citizen ineligible for the office. Divorce is a cultural phenomenon, from another a communicative phenomenon; thus in a society where lack health relationship, is right and natural. Exception of marriage, then divorce attention not only from the perspective of the human person and children is important, but also from the perspective of society, culture, economy and population is significant. As we mentioned in the texts of Islam that man and woman were created for each other, which is the bond of marriage, the physical, psychological, developmental, social benefits. On the other hand, the population quality effect because it causes the children to be deprived of the blessings of family, community delivery. As far as the tradition has been equated with half of religion and after a couple links and formal treaties and customary constitution is established. If the parties fail for various reasons, 
personality, social and environmental live together, they will have to be separated and according to the regulations and rules, the right to adequate and appropriate pair may again decide to find her mate. Divorce as a social issue that involves the legal dissolution of the marriage and the couple's separation, due to the widespread impact of population growth and the transformation of family structure is of great importance. Due to this fact, with the insertion of two incidents of civil registration of deaths and births in current marriage and divorce records annually pays, these statistics as a source of expert studies by experts and researchers are the real beneficiaries.

Research on divorce Kerman can explore and deepen understanding of the phenomenon in question and its wide field of scientific knowledge and to promote the culture of marriage and as well as to develop appropriate social programs for purification of the family and help prevent complications and adverse effects of divorce. The great social problem in no time like the present age, the risk of adverse effects has not been caused by the dissolution of the family. And the divorce rate in the country and consequently the Kerman is increasing day by day as if society towards increasing divorce before, you might be placed on the brink of crisis. Due to the increase of divorce in the country, especially in Kerman and damage caused by this phenomenon on family and community, the necessity arose from a legal perspective consider that the causes of divorce in Kerman. And accompanied by social workers and support public and private institutions have sought to reduce divorce in Kerman.

The necessity arose from a legal perspective consider that the causes of divorce in Kerman. Gradually the consequences of his past lost family, and the current value is affected by the new requirements, so that the traditional family structure is changing and human relations in this. The family has changed, emotions and attitude towards each other and towards the family and family life has changed. And the changes in contemporary family has suffered, the damage that threatens the family discord and divorce is very important. But more important than the consequences that divorce leaves. In this study, aspects of divorce and legal view in Kerman explains.

\section{MATERIAL AND METHODS}

Research methods in the study survey and cross - done. We study population included 50 counts of divorce cases in the city of Kerman who have studied the city's family court the legal reasons for divorce were studied. In this study, due to the limited population and access to divorced people 1 Word studied only 50 cases of divorce cases in the city of Kerman. Thus, the sampling is not used. Units in this study, people who are divorced are in Kerman to check the legal aspects of these divorces are paid. For data collection was used a questionnaire with closed questions. Inventory of the most common tools used by researchers in survey research. In order to determine the validity and after providing for basic items, was evaluated by the supervisor and other professionals were added and some deleted items. . Using SPSS software to summarize, evaluate and interpret the results of both descriptive and inferential using frequency, percentage, mean, correlation coefficient.

\section{RESULTS}

\section{Duration of marriage}

Table 1. Frequency distribution of the duration of marriage

\begin{tabular}{|r|r|r}
\hline Frequency \% & Frequency & Question 1 \\
\hline 6 & 3 & Less than 1 year \\
\hline 32 & 16 & years 2 1 \\
\hline
\end{tabular}




\begin{tabular}{r|r|r}
\hline 36 & 18 & years 5 2 \\
\hline 12 & 6 & years 10 5 \\
\hline 14 & 7 & Over 10 years \\
\hline 100 & 50 & total \\
\hline
\end{tabular}

Financial condition of couples

Table 2. Distribution of the financial situation of spouses

\begin{tabular}{|r|r|r}
\hline Frequency \% & Frequency & Question 2 \\
\hline 4 & 2 & very good \\
\hline 44 & 22 & good \\
\hline 26 & 13 & Middle \\
\hline 26 & 3 & weak \\
\hline 100 & 50 & total \\
\hline
\end{tabular}

\section{financial impact of divorce disputes}

Table 3. Frequency distribution of the financial impact of divorce disputes

\begin{tabular}{|r|r|r}
\hline Frequency \% & Frequency & Question 3 \\
\hline 44 & 22 & too much \\
\hline 34 & 17 & much \\
\hline 10 & 5 & average \\
\hline 8 & 4 & low \\
\hline 4 & 2 & Very low \\
\hline 100 & 50 & total \\
\hline
\end{tabular}

According to the results and graphs can be said on the question of financial disputes in divorce cases in the city of Kerman was very impressive.

Not giving couple's dowry led to divorce?

Table 4. Frequency distribution 


\begin{tabular}{|r|r|r}
\hline Frequency \% & Frequency & Question 4 \\
\hline 2 & 1 & too much \\
\hline 8 & 4 & much \\
\hline 24 & 12 & average \\
\hline 34 & 17 & low \\
\hline 32 & 16 & Very low \\
\hline 100 & 50 & total \\
\hline
\end{tabular}

The difference in payment of incentives divorce and dowry?

Table 5. Frequency distribution

\begin{tabular}{|r|r|r}
\hline Frequency \% & Frequency & Question 5 \\
\hline 8 & 4 & too much \\
\hline 8 & 4 & much \\
\hline 8 & 4 & average \\
\hline 72 & 36 & low \\
\hline 4 & 2 & Very low \\
\hline 100 & 50 & total \\
\hline
\end{tabular}

And finally divorce alimony dispute was not caused by couples

Table 6. Frequency distribution

\begin{tabular}{|r|r|r}
\hline Frequency \% & Frequency & Question 6 \\
\hline 20 & 10 & too much \\
\hline 16 & 8 & much \\
\hline 40 & 20 & average \\
\hline 14 & 7 & low \\
\hline 10 & 5 & Very low \\
\hline
\end{tabular}




\begin{tabular}{|r|r|r}
\hline 100 & 50 & total \\
\hline
\end{tabular}

Non-compliance was effective in divorce wife and refrain from marital relations? Table 7. Frequency

\begin{tabular}{|r|r|r}
\hline Frequency \% & Frequency & Question 7 \\
\hline 6 & 3 & too much \\
\hline 2 & 1 & much \\
\hline 88 & 44 & average \\
\hline 4 & 2 & low \\
\hline 0 & 0 & Very low \\
\hline 100 & 50 & total \\
\hline
\end{tabular}

Lack of information and lack of awareness of women's rights, such as rights of residence of the husband and the divorce was effective?

Table 8. Frequency

\begin{tabular}{|r|r|r|}
\hline Frequency \% & Frequency & Question 8 \\
\hline 14 & 7 & too much \\
\hline 14 & 7 & much \\
\hline 44 & 22 & average \\
\hline 18 & 9 & low \\
\hline 10 & 5 & Very low \\
\hline 100 & 50 & total \\
\hline
\end{tabular}

Legal counseling with couples before marriage reduced to divorce in Kerman?

Table 9. Frequency

\begin{tabular}{|r|r|r|}
\hline Frequency \% & Frequency & Question 9 \\
\hline 28 & 14 & too much \\
\hline
\end{tabular}




\begin{tabular}{|r|r|r}
\hline 14 & 7 & much \\
\hline 26 & 13 & average \\
\hline 18 & 9 & low \\
\hline 14 & 7 & Very low \\
\hline 100 & 50 & total \\
\hline
\end{tabular}

According to the results of this question and that question as before, we came to the conclusion that legal advice before marriage rate can reduce divorce.

\section{CONCLUSION}

The aim of the legislator defending women's rights that no independent income and assets and their livelihoods are possible or avoid adverse effects that couples reach an agreement without the knowledge of the state of inflation in recent years, have agreed on the dowry which is currently due to higher prices, worthless. On the other hand, we can say, the legislator award-worthiness to women who continued living together for many years with integrity and in carrying out the duties of marriage, home and kids would not have been any malfunction. Maybe these two are financial establishment, charge-sheeting men who eat salt, the salt shaker down, and a woman who spent years of his life living together with their values, and parenting and family happiness, such as pulp is discarded. If the aim of the legislator at the current rate of adoption of dowry and schools, to prevent adverse effects of the couple's agreements in recent years' inflation has been done without the knowledge of the situation. Now the question is how legislators in the Implementing Regulations to Article 1085 of the Civil Code of your unit concatenating a note, without any justified reason the couple agreed otherwise in respect of a law of such Note has been appointed: "If the spouses during the marriage dowry payments are calculated in the currency have consent otherwise, will act in accordance with their consent." According to this clause, if the spouses have agreed percentage of a year until the payment of dowries dowry amount is added, how such a deal is approved by the legislature. But agreed to pay the principal amount of dowry is not approved. If the goal is to defend the financial rights of divorced women, by agreement, for example, mentioned that the amount dowry 20 years ago, today is not efficient; For example, if the dowry in the marriage contract signed in 1981, the riyal is stipulated, if the wife is the couple's divorce, the woman defend two million eight hundred thousand would be such an agreement. While the central bank indices dowry payable to such a woman will be different. Do not endorsing a deal, as the article notes, preferred a law of action is not without preferred. The result is that financial support from women during divorce, which he was not responsible, especially in cases where women have jobs, housekeeping jobs and no independent income for a livelihood, it is rational. But this support must be legal ruling on the basis of the current rate and school dowry loose. Forging these rights in practice can sometimes cause side effects and sometimes positive effects; The positive result is when a wealthy couple to secure the rights of his wife. And with payment of dowry and divorce for example, you run the schools or fees to pay the judgment or above, cause for loosening sudden decision to divorce her husband and return him back to life. Adverse effects of the measures, the risk that the financial subservient wife, the wife not to pay salaries. Or after having established, is not willing to provide these rights and, on the other hand, he hated living with his wife and returned to life so that is not possible. Here, the wife remains undecided because on the one hand, a married woman who is required to comply. On the other hand, the pair reluctantly, remain deprived of the benefits of marriage and the loss of this uncertainty can be hard to be more of a problem for a divorced woman. Even in such cases there are two ways: First, the foundation of incompatible and ill-treatment of his wife to divorce him willing to implement the agreement and thus get rid of his rights provision. 
Second way by claiming insolvency of prepaid rights of his wife, split petition to the court of competent jurisdiction, (certificate of non-adaptation Tribunal) be submitted to the court at the hearing session, invited the wife to read to introduce property and defend against claims of insolvency couple he and taking into account the financial situation of the couple to split rights under the contract to take action.

Generally, most important aspects of divorce can be concluded in the city of Kerman this:

The results show the highest rate of divorce among men ages 20 to 30 years, and women marry at a younger age than men. And more divorced women are under twenty years following the separation of the couple checked. The results show that divorced couples who chose webmaster people were unemployed. Or have had jobs. And more divorced wives are housewives and only $8 \%$ of employees that could be of interest to officials in Kerman. The results show that nearly $68 \%$ of the couples divorced in Kerman had less than five years of married life together. According to the results and financial disputes in divorce cases in the city of Kerman has been very effective. The results show that more than ten percent of couple's divorce motives of non-payment of dowry has been in Kerman. And 24 percent of the nonpayment of dowry can be said to be an excuse for divorce. So there must be drawn legal remedies in order to solve the problem. 16 percent of divorce cases in the city of Kerman motives and causes of divorce, they kind of dowry and dowry is addressing. These gaps and problems must be resolved before marriage among couples. And we should talk about them and their transparency. So we should mention legal issues to couples before marriage and even taught to be more careful of their lives. And according to the information obtained in this study was relatively unwilling wife cannot all be causes of divorce in Kerman. It should be noted that couples who are more careful about their sexual relationships. It may raise this leads to divisions. Rights of spouses' lack of information could be important risk factors for divorce in Kerman. So, culture and education legal information for couples before marriage divorce rate can be reduced. Thus, legal advice before marriage divorce rate can be reduced.

\section{REFERENCES}

Barikani, Amina. (2011). to examine the factors referred to divorce, marriage, divorce and complex judicial offices in Qazvin province in 86 years, Proceedings of the National Conference Devin social damage, Faculty of Social Sciences, Tehran University, Iranian Sociological Association.

Pourkhan. (2011). a large comparative study of comparative refer couples to divorce in the family intervention centers in Kerman, Iran Proceedings of the National Conference on Social damage, Faculty of Social Sciences, Tehran University, Iranian Sociological Association.

Hakimpour, Muhammad. (2005). the rights of women in the struggle between tradition and modernity, song publishing new thinking, Second Edition, Tehran.

raisi, F. (2005). Effect of group counseling on reducing adolescent identity crisis districts of three and four of secondary school, senior thesis in General Psychology, Tarbiat Modarres University.

zamani, Ali Akbar. (2013). "the role of the family in providing social security", Journal of Law, the ninth year, the second edition.

farjad, Mohammad Hussein. (2003). the social pathology of family and divorce, publications Mansouri. Ghasemzadeh, M, and Rahpeik, Hassan, and Kiai, Abdullah. (2006). the interpretation of the Civil Code. katozian, N. (2009). civil law in the current order, the publications, the twenty-second edition, Tehran. katozian, Nasser. (2012). the general theory of obligations, the publisher, Sixth Edition, Tehran. mohaggeg damad, Mostafa. (2003). family law legal study of marriage and its dissolution, publishing Islamic Sciences (new ideas in the Islamic sciences), Tehran.

Abrndabady Najafi, Ali Hussein. (2012). an Introduction to Research in the criminal justice system, opportunities and challenges, monthly judgment, the eleventh year. 